tourism and duty-free island status, high-income economy etc. Symbiotic relationships between conservation and development co-exist and complement each other.

Many aspects of sustainable development are practised in Langkawi Geopark. While the protection and conservation of geo-, bio- and cultural heritage sites are emphasised, socio-economic development which benefit the local communities and the national population are also promoted as complementary land uses and activities. The local population, plus enterprising Malaysians from other parts of Malaysia, participate and contribute to the duty-free island activities and the tourism industry. Sustainable nature and ecotourism is promoted. The main attractions are its scenic beauty and recreational opportunities that are associated with natural heritage, history, legends and myths. To promote Langkawi's cultural heritage, the 'kampung' (village) ambience is offered to tourists. Trips to traditional fishing ports and villages are organised, such as to Kampung Kuala Teriang, Padang Mat Sirat, Kampung Kilim, Ayer Hangat and Kampung Kubang Badak Hangat. Traditional villages on the tourist trails include Kampung Mawat, Ulu Melaka, Kampung Raja, Padang Mat Sirat and Kampung Teluk Berembang, Pulau Tuba.

To cater for local and national visitors and tourists, facilities for mass tourism is offered in Pantai Chenang (Chenang Beach) - Pantai Tengah (Middle Beach) corridor while luxury resorts, mainly located in the Datai and Tanjung Rhu areas are more for the upmarket tourists. For marine life lovers, the Payar Island Marine Park offers controlled visits in order to protect its rich marine resources. Annual events attract tourists to the Aerospace Exhibition (LIMA), Le Tour de Langkawi, Langkawi International Ironman Triathlon and Royal Langkawi International Regatta. Facilities for Meetings, Incentives, Conferences and Exhibitions (MICE) are also provided. Recreational forests are popular among local and foreign visitors and tourists. Examples are Temurun Waterfall, Durian Perangin, Gua Cherita, Lubuk Semilang, Pasir Tengkorak and the Dayang Bunting Lake.

Local and regional socio-economic developments are also addressed. Local communities are given priorities in certain job opportunities as well as business ventures such as in the service tourism industry (hotels, resorts and homestay programme); food and beverage (restaurant, hawker stalls, eateries); land and sea transportation (car/van/ rental, taxis, buses, boats, cruises); tour packages and tour guides (island hopping, jungle trekking, geopark trails); cottage industry (handicraft, souvenirs, batik textiles, geoproducts); food industry (downstream marine and agro-based businesses); and entrepreneurship (retail and wholesale businesses).

Education and knowledge-based tourism is also promoted, in line with the geopark concept. Among the initiatives to support this industry include the Geopark Information 
Centre at the foot of Gunung Machincang (Machincang Mountain), Langkawi Research Centre, museums and galleries, Langkawi National Conservatory, geotrails and geoproducts, information brochures and posters for public awareness and training for Stakeholders. Visits to historical places enhance knowledge about historical and cultural heritage. Elements of history and legend can be found at the Mahsuri Mausoleum, the Field of Burnt Rice, legend of Dayang Bunting (Pregnant Maiden), legends of Mat Chincang versus Mat Raya, legends of Gua Cherita (Cave of Stories) and the legends of Telaga Tujuh (Seven Wells).

\section{CONSERVATION AND DEVELOPMENT IN LANGKAWI GEOPARK THROUGH LAND USE PLANNING}

The Langkawi Development Authority (LADA) in collaboration with the Institute of Environment and Development (LESTARI) of Universiti Kebangsaan Malaysia is in the process of preparing the Langkawi Geopark Management Plan (LGMP). Recognising that geoparks are about protection and conservation of land and sustainable development of land and land resources, the approach taken for Langkawi Geopark is implementation through land use planning under the Town and Country Planning Act 1976 (Act 172). This approach was approved and endorsed by the Kedah State Planning Committee (termed the Committee), formed under Sub-Section 4 of Act 172, at the Committee's meeting on $26^{\text {th }}$ August 2010. This means that when completed and approved by the Committee, the LGMP will form part of the Langkawi District Local Plan i.e. it will be read together with the local plan which is already gazetted. This approach was adopted because of several relevant provisions in Act 172:

1. Planning and implementation for sustainable development of Langkawi Geopark would receive the support and approval of the National Physical Planning Council (NPPC) whose functions include (S.2A(2)) “...to promote in the country, within the framework of the national policy, town and country planning as an effective and efficient instrument for the improvement of the physical environment and towards the achievement of sustainable development in the country..." Chaired by the Prime Minister, the NPPC will receive the attention of the highest authority in land use planning and development;

2. At the state level, the State Planning Committee (the Committee) is also responsible for planning for sustainable development. One of the functions of the Committee, under Sub-Section 4(4)(a) is “... to promote in the State, within the framework of the national policy, the conservation, use, and development of all lands in the State..." The on-going preparation of the Langkawi Geopark management plan is a testimony of this function being implemented; 
3. The local plan, under Sub-section 12(3)(a), requires proposals for the use of land; protection and improvement of the physical environment; preservation of the natural topography; improvement of the landscape; preservation and planting of trees. This content of the local plan is in line with the sustainable development goal of Langkawi Geopark;

4. Act 172 provides the instrument with which to gazette the policies, strategies, locations and recommendations related to heritage sites and other proposals for the sustainable development of Langkawi Geopark; and

5. The mandatory requirement for public representations and objections in the structure plan preparation process as well as for public consultations and objections process in the preparation of the local plan will ensure that the geopark management and implementation will be opened for public review at least once in five years when the plans go for statutory review or whenever it is instructed by the Committee.

Besides complying with GGN's six criteria and guidelines for conservation and development of Langkawi Geopark and the Langkawi District Local Plan, the development of the Langkawi archipelago is also guided by the National Physical Plan 2 (NPP2), Kedah State Structure Plan (KSSP) and the North Eastern Corridor Development Plan (NECDP). These are strategic development plans which have adopted sustainable development as their goals, principles and approaches. NPP2 is approved by the National Physical Planning Council; Kedah Structure Plan and Langkawi District Local Plans are approved by the Kedah State Planning Committee and gazetted under the Town and Country Planning Act 1976 (Act 172). Through their policies, strategies, zonings and development guidelines, NPP2, KSSP, LDLP and NECDP guide the development of Langkawi under four broad categories: urbanisation and settlement; tourism infrastructure; nature conservation and agricultural development. Development is regarded as complementary to nature conservation and is based on the concept of sustainability, which is anchored on the principles of social equity, economic efficiency and ecological sustainability.

Similar to Langkawi Geopark's aspirations, the LDLP's vision reflects the sustainable development goals: making Langkawi a tourist destination of international standard, environment-friendly, with local identity and enhancing the quality of life of the people. To achieve this vision, the plan's physical development strategies include: (1) maintaining the natural ecology and agricultural areas; (2) enhancing the quality of local settlements; (3) creating development areas which are well-organised, clientfriendly and exhibiting attractive images; and (4) enhancing and re-arranging the local service centres; creating tourist service centres; and encouraging institutional 
development. Strategies for the non-tangibles include: (1) enhancing human resource development; (2) raising the quality of life; (3) promoting local community participation; (4) promoting research and development; (5) promoting Bumiputera participation in all industries and businesses; and (6) diversifying economic activities and resources. In consonance with the above strategies, the development concepts give emphasis to four aspects: (1) encouraging tourism development of high quality; (2) implementing development which is in balance with the local ecology; (3) emphasising on beautifying and strengthening of the local image; and (4) preserving and conserving the natural resources and environmentally sensitive areas (Map 3).

MAP 3: Langkawi's Land Use Planning and Development Concept

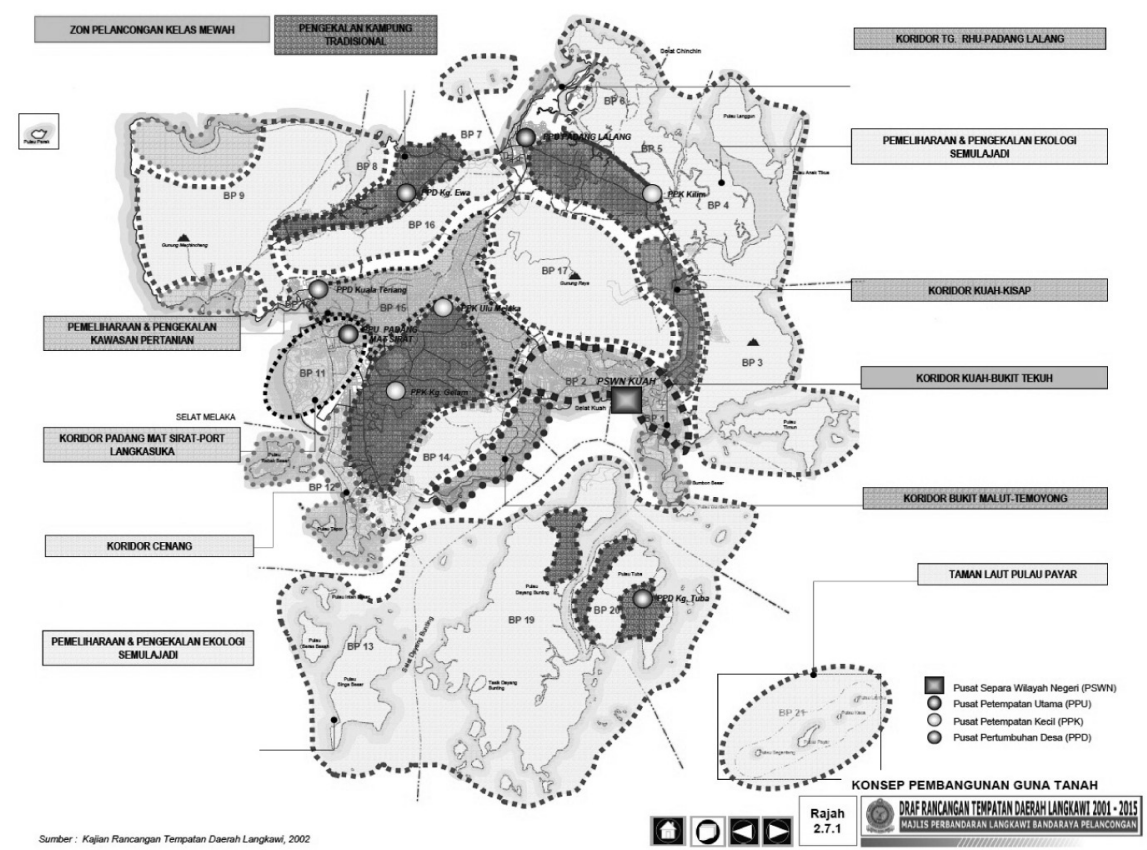

Source: Langkawi District Local Plan 2020.

Under the local plan, the development concept is translated into zoning plans for the planning blocks which are also recognised as the management units of the geopark. Groups of these planning blocks/management units are under mukims (subdistricts) which are recognised as management zones. Map 4 shows the zoning plan of one planning block or management unit. The zoning plan translates spatially the complementary concept of conservation and development. 
The planning and development guidelines of conservation areas in local plans, which could be in the form of geological/biological/cultural areas, sites or monuments, need to be further detailed in special area plans (SAP) to be prepared under section 16B of the Malaysian TCPA 1976. These Conservation Area SAPs, either for one or groups of conservation areas/sites/monuments, should describe in detail the specific land use categories, specific activities that are allowed, density and intensity of development according to the carrying capacity of the area or site, and the design and structure of buildings (if allowed) or physical structures, which must represent and/or highlight the characteristics of the geological/biological/cultural heritage of the area or site. These SAPs will be the basis and reference for the preparation of the development proposal reports which must be submitted together with applications for planning permission under Part IV of the Malaysian TCPA. Sub-section 21A(1)(d) of the Malaysian TCPA requires that development proposal reports include "(i) a description of the land including its physical environment, topography, landscape, geology, contours, drainage, water bodies and catchments and natural features thereon; (ii) a survey of the trees and all forms of vegetation; and (iii) particulars of a building, which may be affected by the development."

In the case of Langkawi, since Langkawi Geopark is relatively new, the above practice has not been duly implemented. Identification of heritage areas or sites, in the form of geological, biological and cultural areas/sites are still on-going and yet to be indicated in site specifics in the current Langkawi District Local Plan. It is expected that once these heritage areas/sites have been identified and acknowledged by the appropriate authorities, the local plan will be amended to include them; special area plans will be prepared; development proposal reports will address these relevant issues; and planning permissions that are issued by the local planning authority will ensure that heritage elements are conserved in or next to development projects, in adherence to the appropriate development guidelines. In this context the role of the local planning authority under the TCPA 1976 (in the case of Langkawi Geopark it is Majlis Bandaraya Pelancongan Langkawi) in implementing Langkawi Geopark, is of utmost importance. 
MAP 4: $\quad$ Langkawi's Land Use Planning and Development Concept

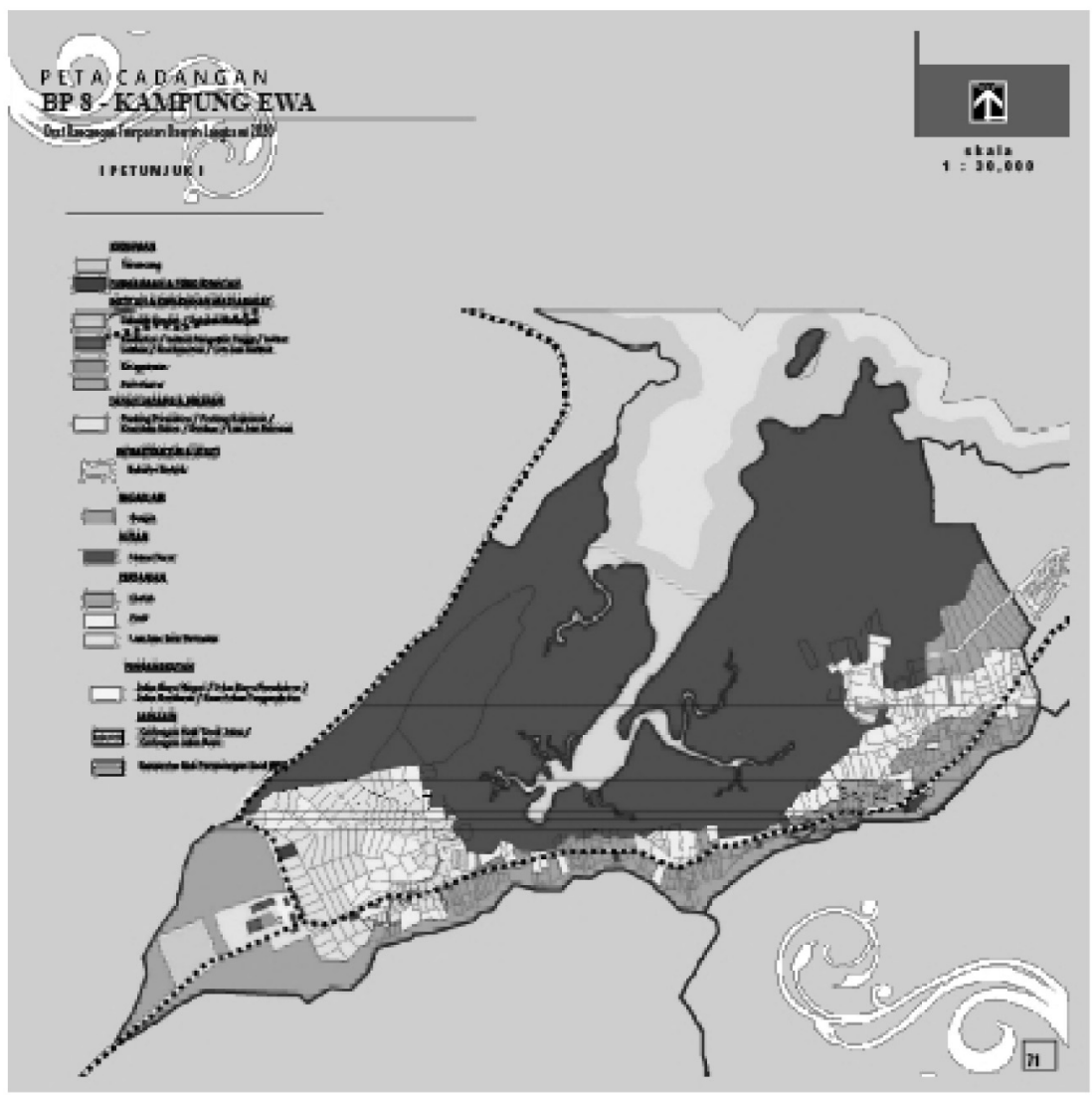

Source: Langkawi District Local Plan 2020.

Realising the complexity of enhancing Langkawi's tourism-related economy and its duty-free island status while at the same time conserving its natural and cultural heritage resources, Langkawi Development Authority (LADA), in partnership with Universiti Kebangsaan Malaysia, has embarked on a project to prepare a comprehensive and holistic management plan for Langkawi Geopark. The proposal for the preparation of Langkawi Geopark Management Plan (LGMP) was approved by the Kedah State Planning Committee on $26^{\text {th }}$ August 2010 and the project started on January $1^{\text {st }} 2011$. A very important condition attached to the approval by the Kedah State Planning Committee is that the LGMP must complement the Langkawi District Local Pelan 2020. If there is a need to amend the local plan to rationalise the Langkawi Geopark within it, this will be done accordingly. This decision emphasises that while nature and cultural 
conservation is promoted through the geopark, socio-economic development that is promoted in the local plan is not being sidelined, since socio-economic development is also part of the geopark's aspirations. The LGMP is still under preparation and is expected to be completed in the not too distant future.

\section{CONCLUSION}

UNESCO's and Malaysia's Heritage Act's definitions, as well as several other definitions of conservation, heritage, development and sustainable development discussed in this article supports the conclusion that there can be conservation with development. The new paradigm that has been adopted by IUCN in its newer protected areas also endorses the conclusion. The description of the global geopark concept by GGN-UNESCO emphasises the symbiotic relationship between conservation and development that exists in global geoparks, provided its planning, implementation and development are within the concept of sustainable development.

Langkawi Geopark has been presented as a Malaysian showcase of implementing sustainable development through a global geopark. The Langkawi Geopark Management Plan is being prepared to be complementary to the Langkawi District Local Plan which is an already gazetted land use strategic development plan at the local level. The adoption of the mukims (administrative sub-districts) of Langkawi District, which is under the Kedah State Government administration, to be management zones, and the adoption of the planning blocks of the local plan to be management units of the geopark is another example of the complementary nature of the two entities. Therefore, although there is no specific law to enforce the Langkawi Geopark, its enforcement can be instituted under the Town and Country Planning Act 1976 (Act 172), besides other laws which are in operation in Langkawi.

\section{ACKNOWLEDGEMENTS}

The contributors wish to express their gratitude to the Planning Malaysia Editorial Board and the Malaysian Institute of Planners' Council for giving the opportunity to publish the articles in this special issue of Planning Malaysia. This is a win-win collaboration effort between researchers and the planning professionals. Appreciation is also attributed to the Langkawi Development Authority (LADA) which provide the opportunity for research on Langkawi Geopark and to be collaborators in the preparation of the Langkawi Geopark Management Plan. LADA's financial contribution is instrumental in UKM's project XX-01-2011. The writers also thank Universiti Kebangsaan Malaysia for providing support to the group on Governance for Heritage Conservation (UKM-GUP-PLW-08-11-048) under the research cluster for Heritage Conservation (UKM-AP-PLW-01-2009). 


\section{REFERENCES}

Aronsun, J. 2006. Development: Definitions and Assumptions. Technology for Developing Countries. Carnegie Mellon. www.techbridgeworld.org. (31 Oct. 2011).

Dexhage, J., and Murphy D. 2010. Sustainable Development: From Brundtland to Rio 2012. Background Paper prepared for considerations by the High Level Panel for Global Sustainability, at its first meeting, 19 September 2010. International Institute for Sustainable Development (IIED).

Freyfogle, E.T. 2006. Why Conservation is Failing and How It Can Regain Ground. New Haven and London: Yale University Press.

Garnett, ST, Sayer, J. and du Toit, J. 2007. Improving the Effectivess of Interventions to Balance Conservation and Development: a Conceptual Framework. Ecology and Society 12(1): 2.(online) URL.: http:// www.ecologyandsociety.org/vol12/ iss $1 /$ art2/

GGN. 2010. Guidelines and Criteria for National Geoparks Seeking UNESCO's Assistance to Join Global Geoparks Network (GGN) (April 2010). http://www. unesco.org/science/earth/doc1geopark/2010guidelines.pdf. (29 September 2010).

Halimaton Saadiah Hashim. 2011. Integrated Management for Heritage Conservation. Keynote address at the National Symposium on Heritage and Conservation 2011, 29 April - 1 May. Kuching, Sarawak.

Halimaton Saadiah Hashim, Rahimah Abdul Aziz, Sarah Aziz Abdul Ghani Aziz and Chan Kim Ling@ Geraldine. 2010. Governance for Geopark: Langkawi Geopark as a Showcase (Trans. Governans untuk Geopark: Langkawi Geopark sebagai Acuan). Akademika, 80, 39-54.

Hall, C. M., and McArthur, S. 1998. Integrated Heritage Management. London: Stationary Office.

Howard, P. 2003. Heritage: Management, Interpretation, Identity. London: Continuum. Ibrahim Komoo. 2010. Geopark as a Model for Regional Sustainable Development. Akademika, 80, 39-54.

Ibrahim Komoo and Patzak, M. 2008. Global Geoparks Network: An Integrated Approach for Heritage Conservation and Sustainable Use. In Southeast and East Asia Geoheritage Conservation, Leman, M.S., Reedman, A and Chen, S.P., eds. Bangi: LESTARI UKM. 1-13

Ibrahim Komoo. 2004. Geoheritage Conservation and Its Potential for Geopark Development in Asia-Oceania. In Warisan Geologi Malaysia (Trans. Geological Heritage of Malaysia), Mohd Shafeea Leman and Ibrahim Komoo., eds. Bangi: LESTARI, UKM.

InfoSheet Ontario 2007. Heritage Conservation Principles for Landuse Planning. Queen's Printer for Ontario, 2007. www.mtc.gov.on.ca/en/heritage/Infosheet Principles 
Jones, Cheryl. 2008. History of Geoparks. In The History of Geoconservation. Burek, C.V., and Prosser, C.D., eds. London: Geological Society, Special Publications, 300, 273-277.

Kerajaan Negeri Kedah (trans. State Government of Kedah). 2007. Rancangan Struktur

Negeri Kedah (trans. Kedah Structure Plan). Kedah State Town and Country

Planning Department.

Lafferty, William M. 2004.From Environmental Protection to Sustainable Development:

The Challenge of Decoupling Through Sectoral Integration. In Governance for

Sustainable Development: the Challenge of Adapting Form to Function, Lafferty,

William M., ed. UK: Edward Elgar, Cheltenham.

Law of Malaysia. 1976. Town and Country Planning Act 1976. Act 172.

Lockwood, Michael, Worboys, Graeme L., and Kothari, Ashish, eds. 2006. Managing

Protected Areas. A Global Guide. IUCN, UNEP, WCPA, USAID, GEF. London:

Earthscan. Sterling, VA.

Majlis Bandaraya Langkawi Bandar Pelancongan (trans. Langkawi Municipal

Council The City of Tourism). 2011. Rancangan Tempatan Daerah Langkawi 2020

(trans. Langkawi District Local Plan 2020), Kedah: Department of Town and

Country Planning of Kedah and Langkawi District Council, Kuah.

McKeever, P.J. 2009. The UNESCO Global Network of National Geoparks: Geological

Heritage and Sustainability. LESTARI Public Lecture Series No. 7. Bangi:

LESTARI, UKM.

Mohd Shafeea Leman, Ibrahim Komoo, Kamal Roslan Mohamed, Che Aziz Ali and Tanot Unjah. 2007. Geopark as an Answer to Geoheritage Conservation in Malaysia - The Langkawi Geopark Case Study. Geological Society of Malaysia Bulletin, 53, June, 95-102.

Mohd Shafeea Leman, Kamarulzaman Abdul Ghani, Ibrahim Komoo and Norhayati Ahmad, eds. 2007. Langkawi Geopark. Bangi: LESTARI, UKM and LADA.

Rosli Hj. Nor. 2008. Conserving National Heritage: Between Context and Practice. Presented at the Round Table Dialogue on Governance and Education Heritage Conservation: Terminologies, Concepts and Contexts. Institute for Environment and Development (LESTARI) Universiti Kebangsaan Malaysia.

The World Bank. 1991. Managing Development: The Governance Dimension, A Discussion Paper August 29, Washington, D.C: The World Bank. http://wwwwds.worldbank.org/external/default/WDSContentServer/WDSP/IB/2006/03/07/0 00090341_20060307104630/Rendered/PDF/34899.pdf. (15 Februari 2011).

UNDP. 1997. Governance for Sustainable Human Development: A UNDP Policy

Document. http://mirror.undp.org.magnet/policy (10 Februari 2011).

UNESCO. 2001. UNESCO World Heritage Centre Background Document on UNESCO World Heritage Cultural Landscapes. Prepared for the FAO Workshop and Steering Committee Meeting of the GIAHS Project: Globally Important Ingenious Agricultural Heritage Systems by Dr Mechtild Rössler UNESCO World 
Heritage Centre.

UNESCO. 2000. UNESCO Geoparks Programme Feasibility Study (unpublished report by Division of Earth Sciences for the UNESCO's Executive Board at the 161st Session in June 2001), Paris: UNESCO.

UNESCO. 1972. Convention Concerning the Protection of the World Cultural and Natural Heritage. Adopted by the General Conference at Its Seventeenth Session. Paris, 16 November. http//: whc.unesco.org/archive/convention-en.pdf.

United Nations Department of Economic and Social Affairs (Division for Sustainable Development). 2009. Agenda 21. (Online).

United Nations. 2001. Managing Sustainable Tourism Development. ESCAP Tourism Review No. 22. New York.

World Commission on Environment and Development (WCED). 1987. Our Common Future. Oxford University Press.

Yahaya Ahmad. 2006. The Scope and Definitions of Heritage: From Tangible to Intangible. International Journal of Heritage Studies, 12, 3, 292-300. 

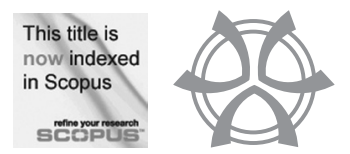

\title{
GEOPARK FOR HERITAGE CONSERVATION: A NEED FOR INTEGRATED PLANNING AND MANAGEMENT
}

\author{
Rahimah Abdul Aziz ${ }^{1}$ \\ Faculty of Social Sciences and Humanities \\ UNIVERSITI KEBANGSAAN MALAYSIA \\ Halimaton Saadiah Hashim ${ }^{2}$ \\ Institute for Environment and Development (LESTARI) \\ UNIVERSITI KEBANGSAAN MALAYSIA \\ Ibrahim Komoo ${ }^{3}$ \\ South East Asia Disaster Prevention Research Institute (SEADPRI) \\ UNIVERSITI KEBANGSAAN MALAYSIA
}

\begin{abstract}
The adoption of 'sustainable development' concept by many countries of the world has drawn attention to the needs to conserve and protect what has been identified as heritage. Due to their symbiotic relationship, the natural and cultural heritage needs to be conserved in an integrated manner, thus requiring integrated planning and management. The geopark concept introduced in 1999 provides this opportunity. The concept highlights the potential socio-economic development while conserving the natural and cultural environment. Because a geopark would contain different kinds of heritage a single integrated plan may help to avoid potential conflicts in managing them. Langkawi Geopark was established in 2007. Its multifaceted features and resources require that it be managed in an integrated manner to enable different stakeholders to be brought onto a common platform. This is to enable differing needs and interests to be taken into account without compromising the need for sustainable development.
\end{abstract}

Keywords: Geopark, heritage conservation, integrated planning and management, Langkawi Geopark

\footnotetext{
${ }^{1}$ Guest Editor, Professor, School of Social, Development and Environmental Studies, Faculty of Social Sciences and Humanities, Universiti Kebangsaan Malaysia, 43600 Bangi, Selangor, Malaysia. e-mail: ikra@ukm.my

${ }^{2}$ Guest Editor, Principal Fellow, Institute for Environment and Development (LESTARI), Universiti Kebangsaan Malaysia 43600 Bangi, Selangor, Malaysia. e-mail: halima@ukm.my/ drhalimaton@, gmail.com

${ }^{3}$ Professor, Director, South East Asia Disaster Prevention Research Institute (SEADPRI), Principal Fellow LESTARI Universiti Kebangsaan Malaysia, 43600 Bangi, Selangor, Malaysia. e-mail: ikomoo@yahoo.com
} 


\section{INTRODUCTION}

Malaysia has generally achieved socio-economic successes that its people can be proud of. However, often times in the development process there exists conflicts between development and heritage protection, between new needs and respect for heritage. In many instances respect for heritage collides with needs for modern infrastructures, which result in heritage taking the back seat in the name of progress and development. Heritage has been known to be given low or obscure priority because it is often taken as possessing very little or no value. It is also perceived as having a tendency to impede or slow down progress.

Expanding human needs and economic activities have resulted in increasing pressure on land creating competition, contestations and conflicts that lead to conservation of heritage being sidelined. This conflict or dilemma is not peculiar to Malaysia. Generally throughout the development process of many developing countries the rule is 'to destroy to build' in order to achieve development objectives. Hence, much land is cleared and jungles destroyed to make way for new infrastructures, industries, offices, housing areas etc. In the process too many old buildings and monuments are destroyed to make way for new and modern ones. This has led to the loss of many invaluable heritages, be it natural or cultural.

However, the adoption of the Convention Concerning the Protection of World Natural and Cultural Heritage in 1972 and the adoption by the United Nations of 'sustainable development' in 1992 promised a better situation. In general sustainable development is popularly accepted to be ... 'development that meets the needs of the present without compromising the ability of the future generations to meet their own need' (United Nations 2009). Attention has been drawn to the needs to conserve and protect what has been identified as heritage for sustainability. The term 'sustainable development' was first used by the Brundtland Commission (WCED 1987) and then adopted at the United Nations Conference on Environment and Development in Rio de Janeiro in 1992. Since the adoption of the 'sustainable development' concept, conservation has begun to assume a place globally and in contemporary Malaysian society. There is an increasing awareness that society can no longer afford to waste resources of any type. With such consciousness heritage too has assumed a new value. Heritage is also now regarded as having the potential to attract tourists to a country other than the conventional attractions such as shopping, sports and recreational activities. In order to ensure that conservation and sustainability objectives are achieved land and land resources need to be planned and managed in an integrated manner. An integrated approach would allow for efficient tradeoffs while minimising conflicts between the needs for development and conservation.

This article discusses the integrated approach to the planning and management of heritage conservation within the context of sustainable development and with a special reference to Langkawi geopark. 


\section{HERITAGE CONSERVATION AND SUSTAINABLILITY}

Initially, when the concept of sustainable development was mooted, it was associated more with protecting and conserving the natural environment than with preserving cultural heritage. However, cultural heritage has since been included in the sustainable development approach because it was recognised that there is a symbiotic relationship between natural and cultural heritage (Halimaton Saadiah Hashim 2011) and that the principles of sustainable development are just as relevant, if not more crucial, to people's daily environment. It was acknowledged that there is not always a clear dividing line between 'nature' and 'culture'. As with natural heritage, cultural heritage calls for continuity between past, present and future. Cultural heritage is not renewable: although valuable new works can be added to it, it cannot be reconstructed once it has been destroyed for it would no longer be the same heritage.

The principles and prerequisites of sustainable development imply that there is a need to conserve important and valuable resources that are then handed down to the next generation. Resources that are inherited and then preserved and conserved to be passed on to future generations are categorised as heritage, which can be both tangible (natural and physical) and intangible (history and culture). In short sustainable development encompasses heritage conservation as it aims at safeguarding heritage while ensuring its accessibility to present and future generations. To put it simply heritage can be regarded as anything that someone wishes to conserve or to collect and to pass on to future generations (Howard 2003:7). However, although anything can become heritage, not everything is heritage unless recognised as such (Howard 2003:7-8). Conservation, on the other hand can be defined as protection from any agent - environmental or human that threaten to destroy heritage. Thus, conservation ultimately is also about promoting good land uses, for the benefit of people, future generations and the land itself (Freyfogle 2006:144). It helps a community to protect its economically valuable physical assets and to preserve its history and environment besides protecting the community's sense of identity and continuity.

The reasons heritage needs to be conserved are because heritage helps shape community identities. It contributes to a sense of community, sense of belonging to a place as well as enhances quality of the environment.

\section{GEOPARK FOR HERITAGE CONSERVATION}

As mentioned earlier sustainable development is about sustainable utilisation of resources, protection and subsequently conserving the natural environment as well as the sociocultural environment. When Agenda 21 (strategic actions for sustainable development) was adopted in 1992 at the Rio de Janeiro United Nations Conference on Environment 
and Development (UNCED) Summit (UNESCO 2000), it included the protection of geological heritage and geodiversity. In line with the development of the sustainable development initiatives, the geopark concept was introduced in 1999. As defined in the Guidelines and Criteria for National Geoparks Seeking UNESCO's Assistance to Join the Global Geoparks Network (GGN April 2010) a geopark is

... a geographical area where geological heritage sites are part of a holistic concept of protection, education and sustainable development. The geopark should take into account the whole geographical setting of the region, and shall not solely include sites of geological significance. The synergy between geodiversity, biodiversity and culture, in addition to both tangible and nontangible heritage are such that non-geological themes must be highlighted as an integral part of each geopark, especially when their importance in relation to landscape and geology can be demonstrated to the visitors. For this reason, it is necessary to also include and highlight sites of ecological, archaelogical, historical and cultural value within each geopark. In many societies, natural, cultural and social history are inextricably linked and cannot be separated.

Geopark is also described as

... geological heritages scenic spot of special geoscientific significance, rare natural attribute and aesthetically ornamental value and with given scale and distribution scope, which integrates other natural scenes and sights and that of cultural interest into a unique natural area. It is not only a site for travel and sightseeing, vacationing and health recuperation as well as cultural recreation at a relatively high scientific level, but also a key protected area of geological heritages and base for geoscientific research and popularisation (http://www. globalgeopark.org/publish/portal1/tab59/ [19 Dec 2010]

This holistic definition by GGN clarifies that geopark is an area where there are geological, biological and cultural conservation through the integrated concepts of protection, education and sustainable development. Initially developed by geologists, the concept and its criteria were taken seriously enough by UNESCO to develop and disseminate the Global Network on Geoparks. By end of September 2011 there is a total of 87 global geoparks in 27 countries that are currently members of the Global Geopark Network (GGN). Of this total 49 are to be found in 18 countries in Europe, 26 geoparks in China and 12 in countries outside of Europe and China (www.earthwork.fsnet.co.uk/ geopark/htm).

Based on the definition and description there are six criteria that need to be observed and adhered to for any area to be recognised as a geopark, namely (i) size and setting, (ii) management and local involvement, (iii) economic development, (iv) education, 